\title{
AGER wt Allele
}

National Cancer Institute

\section{Source}

National Cancer Institute. AGER wt Allele. NCI Thesaurus. Code C106213.

Human AGER wild-type allele is located in the vicinity of $6 \mathrm{p} 21.3$ and is approximately $3 \mathrm{~kb}$ in length. This allele, which encodes advanced glycosylation end product-specific receptor protein, plays a role in both advanced glycation end product recognition and inflammatory signaling. 